\title{
The Dark Knight of the Soul: Weaning and the Problem of Divine Withdrawal
}

\author{
Joshua Cockayne, \\ Department of Philosophy, University of York, York, YO10 5DD \\ jlc513@york.ac.uk
}

Sometimes the truth isn't good enough, sometimes people deserve more. Sometimes people deserve to have their faith rewarded. (Batman, The Dark Knight)

\section{The problem of divine withdrawal}

Succinctly put, the problem of divine withdrawal asks how a God who desires union with us could withdraw from us. In particular, and in contrast to the much discussed problem of divine hiddenness, ${ }^{1}$ the problem is focused on those who believe in God, have experienced closeness to God, desire union with God, do nothing to prevent this union from occurring, yet experience an absence of God's presence.

Let us begin with an example to help make the problem as clear as possible. Mother Teresa is regarded by many as an exemplar of the spiritual life-not only did she commit herself wholeheartedly to a life of spiritual discipline in prayer, meditation and the reading of scripture, but also she devoted her life's work to helping those in some of the most deprived and poverty stricken areas in the world. Yet, in her personal spiritual life, Mother Teresa described moments of great anguish and abandonment by God. Not only moments, though: rather than enjoying a spiritual life typically characterized by experiencing God's presence and a subsequent closeness to him, Mother Teresa's spiritual life was instead typically characterized by experiencing God's absence and a subsequent distance from him. In 1957 she writes,

In the darkness ... Lord, my God, who am I that you should forsake me? The child of your love — and now become as the most hated one. The one - you have thrown away as unwanted - unloved. I call, I cling, I want, and there is no one to answer . . . Where I try to raise my thoughts to heaven, there is such convicting emptiness that those very thoughts return like sharp knives and hurt my very soul. Love - the word — it brings nothing. I am told God lives in me - and yet the reality of darkness and coldness and emptiness is so great that nothing touches my soul. (2007, 186-7)

Mother Teresa's situation is not a unique one. In fact, most, if not all, Christian believers will surely empathise with some of her experiences. So why does God seem absent from individuals who were once close to him if he loves them and desires union with them?

Whilst in many cases, there is a straightforward answer to the question of why a person experiences separation from God-either her sin, some physical or mental pain, or a lack of

\footnotetext{
${ }^{1}$ For a recent discussion of the problem of divine hiddenness see Adam Green and Eleonore Stump's volume Hidden Divinity and Religious Belief.
} 
desire for union with God ${ }^{2}$ - there are more difficult cases, presumably Mother Teresa's, which generate a more difficult question to answer. In such cases,

(1) that person knows that God exists and has shared in some rich experience of God's presence before,

(2) that person has dealt with their guilt and shame and is not living in habitual sin, ${ }^{3}$

(3) that person desires union with God and, ${ }^{4}$

(4) that person experiences separation from God.

Thus, the question which I seek to answer in this paper is this: What morally sufficient reason could God have for withdrawing from such an individual?

The answer that I go on to give is that divine withdrawal can be understood as a kind of spiritual weaning process in which God uses the experience of separation from him as a means

\footnotetext{
${ }^{2}$ The possibilities for why there might be separation between God and an individual are explored in detail by Eleonore Stump (2012) in her discussion of Christ's separation from God on the cross and the cry of dereliction. Stump argues that the reason for Christ's separation from God is that the overwhelming pain of sharing in the suffering of humanity prevents closeness and attention sharing with God whilst Christ is on the cross. For another example of how physical or emotional pain may cause an experience of separation from God, see A.P. Scrutton's (2015) analysis of a Christian approach to depression.

${ }^{3}$ To see more clearly what I have in mind here by 'guilt' and 'shame', consider Eleonore Stump's distinction between guilt and shame:
}

A shamed person and a guilty person each anticipates a repudiation, on the part of real or imagined others, of both the desires of love: (1) the desire for the good of the person in question, and (2) the desire for union with him. But the considerations above suggest that guilt is focused more on the first desire, and shame more on the second. A guilty person anticipating anger and punishment on the part of real or imagined others is anxious about things others may impose on him that are not for his good, at least not in his own view. By contrast, the shamed person anticipating rejection and abandonment on the part of real or imagined others is anxious about marginalization or isolation; his anxiety is directed towards a distance, an absence of union, forced on him by others with whom he himself desires some kind of closeness. $(2010,144)$

${ }^{4}$ An example of how lack of desire of an agent may cause experience of separation, see Anthony Bloom's discussion of prayer in which he claims

[i]f you look at the relationship [with God] in terms of mutual relationship, you will see that God could complain about us a great deal more than we about Him. We complain that He does not make Himself present to us for the few minutes we reserve for Him, but what about the twenty-three and a half hours during which God may be knocking at our door and we answer "I am busy, I am sorry" or when we do not answer at all because we do not even hear the knock at the door of our heart, our minds, of our conscience, of our life. So there is a situation in which have no right to complain of the absence of God, because we are a great deal more absent than He ever is. $(1970,2)$ 
of spiritual maturation. ${ }^{5}$ Metaphorically speaking, the sweetness of breast-milk must be replaced with something more nutritious and enriching for the individual. And although this process is painful for both the mother and the child, it is a process which aims at a closer union and is this future benefit which justifies the suffering inflicted. This metaphor has been used in various places in the spiritual literature. Here, I focus on two such cases: Søren Kierkegaard's weaning stories in the 'Exordium' from Fear and Trembling, and then John of the Cross's discussion of weaning in The Dark Night of the Soul. Having discussed examples from the spiritual literature, I then ask how absence and separation could bring about a closer, or more mature union between persons.

\section{Weaning and the problem of divine withdrawal in Kierkegaard}

A theme which is repeated in Kierkegaard's entire authorship, but which receives its most detailed treatment in the pseudonymous Fear and Trembling, is that the spiritual life requires suffering and sacrifice. ${ }^{6}$ Using the pseudonym 'Johannes de Silentio', Kierkegaard explores the story of the Akedah and God's command to Abraham to sacrifice his son, Isaac. The discussion of whether Abraham must make a 'teleological suspension of the ethical' (FT, 54) ${ }^{7}$ has received considerable attention in the secondary literature, particularly in reference to the discussion of divine command theory and the nature of religious obligation. ${ }^{8}$ However, as many commentators draw attention to, Fear and Trembling is predominantly a work about faith, rather than ethicsalthough there are ethical issues discussed in the text, primarily, this text is about the spiritual life. ${ }^{9}$ Using the story of Abraham as a starting point for discussion, Johannes seeks to pick out

\footnotetext{
${ }^{5}$ Something which I do not go into here, but which is worth taking note of, is that the metaphor of weaning is one of the few feminine metaphors to describe God in both Scripture and also the spiritual literature. This is particularly interesting in the context of discussing the withdrawal of God's presence, as the Hebrew 'Shekinah' which is used when referring to God's presence in the Old Testament is a grammatically feminine word.

${ }^{6}$ For a detailed discussion of this theme in Kierkegaard's authorship, see Simon D. Podmore (2013).

${ }^{7}$ I use the International Kierkegaard Commentary system of abbreviation to refer to the Kierkegaard's Writings series throughout, and refer to the following works:

EO1: Either/ Or, Part 1

FT: Fear and Trembling
}

SUD: The Sickness Unto Death

${ }^{8}$ See Philip L. Quinn's discussion of Fear and Trembling in his article 'Moral Obligation, Religious Demand, and Practical Conflict', for instance (2006, 83-91).

${ }^{9}$ As Evans notes,

Fear and Trembling is not the book on which to focus if one wants to understand Kierkegaard's own views on ethics. Kierkegaard's primary concern in creating the pseudonym Johannes de Silentio, and through him, Fear and Trembling, is not to develop an ethical theory, but to combat widespread nineteenth-century assumptions about the nature of theology and its relation to philosophy and to culture.... The book is primarily about faith, and the role faith should play in the formation of the self's identity. (2004, 62) 
what it is about Abraham that makes him a hero of the faith, or a 'knight of faith' (FT, 38) and an example of the spiritual life lived well.

Although the theme of suffering and separation from God spans the entirety of Fear and Trembling, for the purposes of this paper, I focus here on how these themes are introduced in Johannes' Introduction to the Akeadh in the 'Exordium', or 'Tuning Up', as it sometimes translated. Here, Johannes recites four different retellings of the Akedah from the perspective of a man who is obsessed with understanding Abraham's faith. Whilst these four fictional Abrahams make similar outward movements to the real Abraham, their internal response to the situation differs in various ways, and thus are not examples of faith, for Johannes. In the first story, Abraham presents himself as a monster to Isaac to protect Isaac's trust in God. In the second, Abraham loses his faith and trust in God after the event. In the third, Abraham cannot understand why his actions are not sinful and how God could require Isaac's sacrifice from him. And finally, in the fourth retelling, Abraham despairs at the moment of sacrifice, and Isaac notices this but never speaks of it. I will not say much more about the importance of these imagined retellings of the Akedah here, but it is worth noting that these stories all attempt to rationalise or humanize Abraham's actions in some way. Crucially, however, none of these four Abrahams have faith, or at least not the faith which Johannes describes in the remainder of Fear and Trembling.

Alongside these retellings of the Akedah, are four short and intriguing stories of a mother weaning her child. These stories, or parables, as I will call them, are not explained or referred to at any point in the proceeding text and they do not play a crucial role in the discussion which follows. ${ }^{10}$ These parables can, however, give us some insight into the problem of divine withdrawal, or so I will argue. ${ }^{11}$ Although they do not follow on immediately from one another in the text, I present them together here:

When the child is to be weaned, the mother blackens her breast. It would be hard to have the breast look inviting when the child must not have it. So the child believes that the breast has changed, but the mother- she is still the same, her gaze is tender and loving as ever. How fortunate the one who did not need more terrible means to wean the child! (FT, 11)

When the child has grown big and is to be weaned, the mother virginally conceals her breast, and then the child no longer has a mother. How fortunate the child who has not lost his mother in some other way! (FT, 12)

When the child is to be weaned, the mother, too, is not without sorrow, because she and the child are more and more to be separated, because the child who first lay under her heart and later rested upon her breast will never again be so close. So they grieve together the brief sorrow. How fortunate the one who kept the child so close and did not need to grieve any more! (FT, 13)

\footnotetext{
${ }^{10}$ For a collection of Kierkegaard's parables, see Thomas C. Oden's The Parables of Kierkegaard. Oden also gives an excellent overview of the use of parable in Kierkegaard's writings in his introduction to the text.

${ }^{11}$ For an interesting account of the role of narrative in philosophy and theology, see Eleonore Stump's discussion of Franciscan knowledge in Wandering in Darkness ((2010), 1-64).
} 
When the child is to be weaned, the mother has stronger sustenance at hand so that the child does not perish. How fortunate the one who has this stronger sustenance at hand. (FT, 14)

All four parables focus on the separation and subsequent distance between mother and infant in the process of weaning. In the first two parables, the mother deliberately covers or changes the appearance of her breast in order to encourage the process of weaning, and the result, from the perspective of the child, is an experience of separation from the mother. In the third story, we are told that both the mother and the child suffer in some way through the process of weaninga level of intimacy is lost as the child begins to learn how to be independent. However, there is a kind of resolution to the parables in the fourth story, as we are told that the mother does not aim at needless suffering, but that she intends to provide 'stronger sustenance' for the child in replacement for the milk. Immediately we see that these examples tell a story of an experience of separation and loss of intimacy, but one which has a greater purpose, and a purpose which is beneficial to both the infant and the mother. ${ }^{12}$

Although the weaning parables are not precisely parallel to Johannes' retelling of the Akedah,,$^{13}$ they do provide an introduction to some of the themes which are developed later in Fear and Trembling. As Vanessa Rumble describes it,

[1] $\mathrm{n}$ both the tales of Abraham and the stories of weaning, we are confronted at eerie proximity with the prospect of an absent, incoherent, and violating deity, an image of nightmarish proportions, the fact that God's commands are madness, and God's providential care of the smallest and most vulnerable non-existent. $(2015,259)$

The weaning stories present a very human, and relatable story of loss and separation for the purpose of achieving some higher good. Although Johannes (or, at least the imagined character we are presented with at the beginning of the 'Exordium') does not understand Abraham's actions, the mother's actions and the infant's experience of loss, in contrast, require no justification. The good which the separation of the child from the mother aims at is transparent in a way that Abraham's separation from God's goodness and Isaac's separation from his father's

${ }^{12}$ There has been some recent scholarly attention regarding why these stories are included (see Vanessa Rumble (2015) and Jacob Howland (2015), both of which are included in the recent Kierkegaard's Fear and Trembling: A Critical Guide), but the significance of their inclusion is often debated. Some scholars have maintained that the use of an explicitly feminine metaphor with no further discussion is an attempt to indirectly communicate with Regine Olsen, the woman who Kierkegaard broke off his engagement to. Although there is surely some truth in this, the reference to biographical facts from Kierkegaard's life does not fully explain the role of the weaning parables, nor should it concern us greatly here. However, as Vanessa Rumble notes, in her discussion of Kierkegaard's weaning stories, it seems strange that Kierkegaard would have any knowledge about weaning, and so it is odd that this metaphor is included; his Mother is never mentioned in his journals, and his engagement with Regine was brief and certainly did not result in children.

${ }^{13}$ The first weaning story, in which the mother blackens her breast, seems similar to the story of Abraham presenting himself as a monster to protect Isaac's faith in God. However, it is not obvious that the remaining three stories map on neatly to the last three re-tellings of the Akedah, and this direct comparison should not be given too much weight in determining the significance of the weaning parables. 
love are not. So whilst Isaac does not understand his father's actions, Abraham does not understand the reason behind God's commands, and the crying infant who experiences separation from her mother does not comprehend the suffering she feels, all three receive something back by their movements. For Abraham, his only beloved son. For Isaac, his life. And for the weaned child, a different, but equally intimate relationship with her mother.

This higher good which separation aims at, I think, is a kind of maturation in relationship. As Edward Mooney tells us, according to Johannes,

To achieve independence-in-relationship, separation that simultaneously acknowledges profound dependence, is exactly the project of Kierkegaardian selfhood...More specifically, resignation of something of utmost value (in this case, the child to be weaned), coupled with the assurance that it will be returned, is Johannes de Silentio's basic characterization of faith. Faith is the process of weaning the child and welcoming its return. (1991, 31; emphasis in the original)

For Johannes, although weaning plays no further role in Fear and Trembling, it is, perhaps, the best explanation of Abraham's actions that we can give (if any sensible explanation can be given at all). The movement of faith is described later in the text as a kind of 'double-movement' (FT, 36). Faith requires a resignation, or a giving up of something which is of great of value, but crucially, faith is not simply the act of resignation, for Johannes. But rather, it is the receiving back which is crucial-Abraham gives up that which is most precious to him (his only son) and this act of resignation allows for his receiving of Isaac as a gift from God. To put it another way, as Christ tells us in the Gospel according to Matthew, 'Those who find their life will lose it, and those who lose their life for my sake will find it' (Matthew 10:39). This double-movement of faith can be seen plainly and comprehensively in the metaphor of weaning - to understand the separation or resignation of the infant, we must see the value that comes from weaning-namely, that it is not just an act giving something up, but an act of receiving back. Whilst suffering and separation are an essential part of the weaning parables, it is important to see that the fourth weaning parable speaks of the ultimate benefit of this: 'the mother has stronger sustenance at hand so that the child does not perish' (FT, 14).

The metaphor of weaning in Fear and Trembling presents us with the basic features which will form the basis of the response to the problem of divine withdrawal which I develop. Namely, that withdrawal can be a means of maturation, and, ultimately, it can be a justifiable infliction of harm for some higher good. Before going on to explain how Kierkegaard's discussion of weaning as a spiritual metaphor can provide us with an answer to the problem of divine withdrawal, I focus on another use of this metaphor which can help us to develop this account, namely, John of the Cross's use the weaning metaphor in The Dark Night of the Soul. ${ }^{14}$

\section{Spiritual weaning in The Dark Night of the Soul}

\footnotetext{
${ }^{14}$ For historical examples of weaning in scripture, see Genesis 21:8, 1 Samuel 1:22-24, 1 Kings 11:20, Hosea 1:8 For metaphorical discussions of weaning in scripture, see Psalm 131, Isaiah 28:9,1 Corinthians 3:1-4, Hebrews 5:13 and 1 Peter 2:2.
} 
In The Dark Night of the Soul, John of the Cross, the 16th Century Spanish mystic, explores the themes of suffering and separation from God. For John, the 'dark night', in which our spiritual senses are dulled and the believer experiences God as absent, is a means of developing spiritual maturity and, eventually, loving, sensual union with God, the beloved (2002, 25). As with Johannes' discussion of faith, for John, suffering and separation from God do not detract from faith or undermine belief in God in any way, that is, they do not pose an epistemic problem for us. Rather, suffering and separation from God are an important stage in the development of faith and union with God. ${ }^{15}$

In the two books expounding the meaning of the poetry of The Dark Night of the Soul, John discusses the kind of spiritual development which the soul must undergo in order to reach loving union with God. This begins, in the first book, with his discussion of the "The Night of Sense' in which God purifies the believer. Similarly to Johannes de Silentio, John uses the metaphor of weaning to guide his discussion of spiritual development. It is in the Dark Night of the Soul that we find perhaps, the most detailed and prolonged use of weaning as a spiritual metaphor. Spiritual development begins, John tells us, '[o]nce the soul has completely surrendered to serving God'. In this stage, he writes,

[S] he is nurtured and caressed by him, just like a tender baby with its loving mother. The mother holds the child close in her arms, warming it with the heat of her breasts, nourishing it with sweet milk and softened foods. But as the baby grows, the mother gradually caresses it less. She begins to hide her tender love. She sets the child down on its own two feet. This is to help the baby let go of its childish ways and experience more significant things.

The Grace of God is just like a loving mother...Through grace, the soul discovers sweet spiritual milk and effortlessly drinks in all the things of God. Through grace, God gives the soul intense delight in spiritual practices, just as a loving mother places her breast tenderly into the mouth of her child. $(2002,36)$

For John, this spiritual sweetness which occurs at the beginning of faith brings with it a pleasure in engaging with spiritual practices - the individual finds times of prayer to be blissful and 'fasting makings her happy' $(2002,36)$. According to John, '[b]eginners feel such passion about divine things and are so devoted to their spiritual practices' (2002, 37). It is this first stage of the beginners' spiritual joy, which John uses the metaphor of the breastfeeding infant to illustrate. At this stage in the spiritual life, God is the source of all of her spiritual nutrition, and without the constant joy of spiritual practice, she cannot develop spiritually.

However, this spiritual milk which is appropriate for beginners is unable to provide and sustain the believer or allow for mature union with God. John goes on tell us that

[j] ust as Abraham made a great feast when his son Isaac was weaned, so there is rejoicing in heaven when God removes the baby clothes from the soul. He is setting her down from his arms and making her walk on her own two feet. He removes her lips from the

\footnotetext{
${ }^{15}$ It is not obvious whether Kierkegaard is explicitly referring to the John of the Cross in use of the weaning parables, and as far as we are aware, Simon D. Podmore claims, Kierkegaard was not familiar with John's work (2013, 80-1). Additionally, it is worth noting that Kierkegaard was often ambivalent or even dismissive about mystical texts.
} 
milky breast and replaces the soft sweet mush of infants with the crusty bread of the robust. $(2002,75)$

In order for there to be any meaningful spiritual development, God must remove the joy of his presence which accompanies the spiritual life of the beginner. This withdrawal and experience of separation is important not only for the believer's relationship with God, but also for her own development. The result of spiritual weaning, and the experience God's absence, John goes on to tell us, is that the soul learns to commune with God 'more respectfully...and more courteously' $(2002,76)$. Spiritual maturity, through the experience of God's absence, begins with a greater self-awareness; 'from this dry night', John writes, 'first flows self-knowledge and from this source arises knowledge of God' (2002, 78-9). Absence from God brings a perspective to the believer of her own insignificance, and God's greatness, majesty and, ultimately gives the believer a sense of her sinfulness in comparison to God's perfection. This realisation and experience of absence is accompanied by the development of the virtue of humility, according to John:

What the soul draws also from the aridity and emptiness of the night of desire is spiritual humility. Through humility, acquired along with self-knowledge, the soul is purified of the imperfections of spiritual pride into which she stumbled during her time of prosperity. $(2002,79)$

As we see with cases such as Teresa's, for instance, this process of weaning and spiritual growth is a slow process which often takes years to come out of, if it at all. The move into spiritual maturity is marked by the move from the Night of the Sense, to what John calls the 'Night of the Spirit'. However, he goes on to tell us, 'God may not immediately move her into the night of the spirit...Instead, the soul may spend years cultivating mastery before she is ready to face the impenetrable darkness that leads to union.' $(2002,89)$. So, John tells us, spiritual weaning is not a process which is finished quickly. This experience of God's separation and the lack of joy in the spiritual life may continue indefinitely in fact.

What we see developed in John's discussion is a more explicit connection between spiritual maturity and the metaphor of weaning which is only hinted at in Kierkegaard's writing. In next section, I apply this metaphor to the problem of divine withdrawal and consider whether a response is possible from what has been presented so far.

\section{The problem of divine withdrawal and the Dark Knight of the Soul}

Does this metaphor give us any help in discussing the problem of divine withdrawal? And, in particular, does it give us an answer as to why God would withdraw from someone who meets conditions (1)-(4)? The claim that I have been exploring through both Kierkegaard's and John of the Cross's discussions of weaning is that separation from God for some higher purpose is justifiable. In Fear and Trembling, this is presented as the basis of faith and explained in parallel to Abraham's receiving Isaac back with joy. In the Dark Night of the Soul, this claim is given a more detailed explanation, in that separation from God brings about spiritual maturation and development of spiritual virtues such as humility. Are these interpretations of weaning defensible? Or, to put the question more succinctly and more generally: Can someone's absence ever be beneficial for one's maturation? 
It will be helpful to see this question not just a spiritual one, but as a more general question about relationships between persons. So how can absence and separation play a role in the development of union between persons? The hypothesis, that separation or withdrawal can create a deeper union of love has some support in the psychological and sociological literature through the discussion what is often called the 'de-adaptation process'. Donald W. Winnicott, uses the early years of a child's life to explain the maturation process which occurs as the infant moves from an absolute dependence on its mother towards a kind of independence. 'Maturity of the human being', Winnicott writes,

is a term that implies not only personal growth but also socialization. Let us say that in health, which is almost synonymous with maturity, the adult is able to identify with society without too great a sacrifice of personal spontaneity; or, the other way round, the adult is able to attend to his or her own personal needs without being antisocial, and indeed, without a failure to take some responsibility for the maintenance or for the modification of society as it is found. $(1965,82-3)$

For Winnicott, maturity is defined in the ability to attend to one's own needs appropriately. In the first few months of its existence, however, the child is so dependent on her mother for her practical needs, that there is no sense of individuality about the child. Winnicott calls this stage 'absolute dependence' $(1965,83)$. At this stage, any impingement of the infant's needs or failure of adaptation, from the caregiver, can result in serious interferences with the infant's development, and the maturational process, Winnicott notes $(1965,85)$. Axel Honneth, in writing about Winnicott's discussion of maturation, describes that, in this early stage, there is no sense of individuality about the child; mother and child exist in what Honneth calls 'undifferentiated intersubjectivity' or 'symbiosis' (1995, 98).

Winnicott maintains that it is only by moving away from this absolute dependence stage, that the infant is able to go through the process of de-adaptation. The second stage is a kind of relative dependence, in which the child begins to be aware the world beyond the mother, and develop a sense of self. This can only occur when the infant is able to perceive the mother not as part of herself, but as an object in her environment and something which is beyond her control. According to Winnicott, this stage is a kind of gradual de-adaptation which allows for the development of reflection and independent thought $(1965,86)$. He uses the example of feeding to show this:

Think of an infant expecting a feed. The time comes when the infant can wait a few minutes because noises in the kitchen indicate that food is about to appear. Instead of simply being excited by the noises, the infant uses the news item in order to be able to wait. $(1965,86)$

The less dependent the infant becomes on the mother, the more able she is to process and understand her environment, and eventually form relationships with people other than the caregiver. This gradual de-adaption allows for the slow development towards independence and maturation, something which is not fully achieved until adulthood, for most people, Winnicott tells us $(1965,91)$. It is this move away from absolute dependency which is the mark of maturity, according to Winnicott's analysis. 
Honneth describes this process of gradual de-adaptation as the basis of loving relationship; it is essential that independence is achieved in order for love to develop, he thinks $(1995,101)$. Honneth claims that this gives support to 'the hypothesis that all love relationships are driven by the unconscious recollection of the original experience of merging that characterized the first months of life' $(1995,105)$. 'The inner state of symbiotic oneness', he goes to write,

so radically shapes the experiential scheme of complete satisfaction that it keeps alive, behind the back of the subject and throughout the subject's life, the desire to be merged with another person. Of course, this desire for merging can only become a feeling of love once, in the unavoidable experience of separation, it has been disappointed in such a way that it henceforth includes the recognition of the other as an independent person. (1995, 105)

If Honneth is right, that both dependence and separation are required for a relationship of love, then it is plausible to see the description of the dark night of the soul in terms of de-adaptation. Whilst an agent might be entirely dependent on God for her spiritual life, she exists in symbiosis with God; she does not have a good level of self-awareness, or God awareness. Hence why, for John of the Cross, separation from God brings with it a kind of humility. In being aware of oneself in relation to God, an agent is able to perceive her own shortcomings more perceptively. In her state of symbiosis, an agent does not have a union of love with God; the relationship is too one sided. In order for this to be possible, and for their relationship to mature, God must allow for de-adaptation to occur. ${ }^{16}$

\footnotetext{
${ }^{16}$ This claim seems relevantly similar to claims Kierkegaard makes elsewhere. Namely, that an overexposure to God's goodness can have a detrimental effect to the purpose of bringing about loving union; as the later Kierkegaardian pseudonym Anti-Climacus describes it, this can result in a kind of 'intoxication' in which
}

[t]o exist before God may seem unendurable to a man because he cannot come back to himself, become himself. Such a fantasized religious person would say (to characterize him by means of some lines): "That a sparrow can live is comprehensible; it does not know that it exists before God. But to know that one exists before God, and then not instantly go mad or sink into nothingness!' (SUD, 32)

However, as an anonymous referee has helpfully pointed out, it may not be the case that withdrawing from another person is an effective method of deepening a relationship of love in all contexts. As the referee drew my attention to, Kierkegaard alludes to this in Either/Or, in which the pseudonymous author Johannes the Seducer claims that letter writing is often a better form of seduction than physical presence:

When she has received a letter, when its sweet poison has entered her blood, then a word is sufficient to make her love burst forth... Only traces of ardor can be used in a conversation. My personal presence will prevent ecstasy. If I am present only in a letter, then she can easily cope with me; to some extent, she mistakes me for a more universal creature who dwells in her love. Then, too, in a letter one can more readily have free rein; 
The analogy of weaning is apt to describe this experience of separation discussed in the problem of divine withdrawal. Strictly speaking, although the mother withdraws her breast from the infant in this process, she never withdraws entirely from the infant. The change in the infant's perception of her mother is enriched by the de-adaptation process, but she never returns to the sweetness of the breast. By the time the child reaches adulthood, the loss of this sweetness is hardly a loss at all. The sweetness of milk is replaced by a deep and two-sided union of love. ${ }^{17}$ Spiritually, this gives us a model of what maturation looks like-an agent's apparent closeness to God, after a period of great suffering and separation, gives way to an appreciation of God's perfection, her own weaknesses, and ultimately a more genuine union. ${ }^{18}$

Is this an adequate response to the problem of divine withdrawal, and the question of why God might withdraw from someone who meets conditions (1)-(4)? In the next section, I discuss some potential objections to the answer I have given.

\section{Objections: Absolute dependency and spiritual consent}

Before concluding, I consider two important objections to the claim that my account of spiritual weaning can give a good response to the problem of divine withdrawal.

First, it might be argued, that unlike a weaned child, human beings never move away from, or ought not to move away from, absolute dependency on God. However, the position I have developed here, argues that both dependence and independence are important for union with God. It is important to note that this tension (between absolute dependency and independence of relationship) is not one that I have introduced to Christian theology, but, rather, I have merely drawn attention to the fact that there is an existing tension in Christian theology between our absolute dependence on God and the need for independence in our relationship with God. Whilst, on the one hand, Scripture affirms that we can do nothing without God, (Christ tells his disciples that 'apart from me you can do nothing', for instance (John 15:5)), on the other hand, it also emphasises the need for our initiative and independence in relationship with God ('Show me your faith apart from your works, and I by my works will show you my faith', the Epistle of James tells us (James 2:18)). In light of this, it is not my intention to entirely resolve the tension between dependency and independence, but to note that in some sense, both are important for Christian theology.

One way of thinking about how this tension might be resolved, but something which I do not have space to develop entirely, is that talk of absolute dependency in Christian theology can be explained ontologically. That is, we are entirely dependent on God for our continued

in a letter I can throw myself at her feet in superb fashion, etc., something that would easily seem like nonsense if I did it in person, and the illusion would be lost. (EO1, 286)

${ }^{17}$ This way of thinking about separation is similar to Sarah Coakley's analysis of John of the Cross, she writes that "what appears to be divine "hiding" is actually a unique form of divine selfdisclosure for the purposes of redemption' (2016, 230).

${ }^{18}$ As has been suggested to me, we may even be able to make sense of God's withdrawal from a group of people in order to bring about closer union, such as in God's withdrawing from Israel at various places in the Old Testament, for instance. 
existence and without his willing, we would cease to exist. However, to talk of independence in relationship with God, is talk of our will and response to God-whilst we are entirely ontologically dependent on God, in order for a relationship of love to be developed, there needs to be some independence of the will. This is not entirely adequate as a response, however, since relationally, a deeper union of love will also require an increased dependence on God (in the same way that a marriage results in increased dependence on the spouse). However, this is very different to the kind of dependence of a newborn and a mother-in order for there to be increased dependency in marriage, for instance, there must be a mutual submission of the will, and this looks starkly different to the relation between mother and newborn. Our relation to God, then, is one of ontological dependence, and aims at growing towards the kind of relational dependence, but this dependency must be willed, rather than inflicted. It is through the experience of divine withdrawal, that an individual may wholeheartedly will a relational dependency on God.

The second objection which it will be important to address is the question of whether God could ever have a morally sufficient reason for allowing the kind of suffering which is caused by his withdrawing. What would count as a morally sufficient reason for this kind of suffering? First, we might think, the suffering must benefit the agent in some way. As Eleonore Stump puts this point,

[i] $\mathrm{f}$ what is bad about suffering is that it undermines a person's flourishing or that it deprives her of the desires of her heart or both, then a benefit that constitutes a morally sufficient reason for God's allowing suffering must be something that somehow defeats the badness of suffering so understood. $(2010,13)$

It is also plausible to think that not every kind of benefit would be count as a morally sufficient reason for allowing you to suffer. To see this, we must distinguish between two kinds of benefit: negative benefits and positive benefits. To put this succinctly: benefits which prevent some harm from occurring to you are negative benefits, whereas benefits which improve your wellbeing without preventing harm are positive benefits. We can see what this distinction amounts to by using a medical analogy. I can negatively benefit you by giving you chemotherapy, something which will cause you short-term harm, but which will prevent you from experiencing the significant long-term harm of sickness and potentially, death. Or, to give another example of a negative benefit: I might harm you by rugby tackling you in the middle of the street, but thereby prevent you from experiencing the harm of falling under the approaching bus. Alternatively, I might positively benefit you by allowing or causing harm. For example, by performing cosmetic surgery on you to straighten your wonky nose, I would allow or cause you harm which would bring about some kind of benefit for you, but crucially, I would not prevent harm from occurring, since the benefits would be only positive. Or, by locking you in a cellar for four years, I cause you significant harm, but it might have the positive benefit of giving you an appreciation for life's simpler pleasures. ${ }^{19}$

What is the significance of this distinction for the problem of divine withdrawal? Well, it seems to be relatively unproblematic that I could harm you to bring about negative benefit without your consent, at least in some instances. Thus, for example, if you have an accident and

\footnotetext{
${ }^{19}$ Stump considers this example of positive benefit in her discussion of the morally sufficient reasons for God's allowing suffering $(2010,392)$.
} 
were knocked unconscious and a doctor performed invasive but life saving surgery on you, it seems intuitive that the harm of the life-saving surgery, though non-consensual, is permissible. We would no doubt say the same about my rugby tackling you away from oncoming traffic. Let us suppose, however, that whilst you were unconscious, the doctor also decided to fix your wonky nose without your consent, would we find this kind of harm permissible? Or, suppose my locking you in a cellar for four years brought about significant positive benefits, would this be permissible? At least intuitively, positive and negative cases look different. In cases of negative benefit, consent looks less important. But in cases of positive benefit, consent is vital.

Thus, it looks like the following two criteria are important for giving an account of the morally sufficient reasons for allowing suffering:

i) The suffering is beneficial to the agent, and,

ii) The benefit of this suffering, if non-consensual, must be a negative benefit rather than a positive benefit. ${ }^{20}$

So, can we give a morally sufficient reason for why God allows people to suffer? One way of answering this question is to say that, in some way, all suffering is negatively beneficial to humans. This kind of response has been developed by Stump (2010) to answer to the question of why human beings suffer. According to Stump, human suffering allows for the possibility of eternal and freely chosen union with God and the negative benefit of this suffering is that it prevents eternal separation from God. We do not need to worry about the details of Stump's account here, but we should note that this response will not straightforwardly explain why God allows agents to suffer instances of divine withdrawal which meet conditions (1)-(4). Whilst suffering may be justified as a means of preventing permanent union with God, it does not seem to give a good response to cases such as Mother Teresa's— those people who have already begun to be sanctified by God, and who will one day enjoy permanent union with Him. To put to the problem more succinctly - the very case which generates the problem of divine withdrawal is a case in which negative benefit cannot be appealed to in meeting the consent constraint. ${ }^{21}$ The reason that this is a problem for my account is that, amongst the conditions required for the problem to be generated is condition (2), the person has dealt with their guilt and shame and is not living in habitual sin. In other words, an appeal to the negative benefits received will not help if the case of weaning meets condition (2). The benefits received from spiritual weaning will thus be entirely positive, and the constraint condition is not met by my account.

\footnotetext{
${ }^{20}$ Stump develops these conditions in Wandering in Darkness (2010, 378-386) and Paul Draper (2011) gives a detailed account of why he thinks Stump fails to meet these conditions in his review of the book.

${ }^{21}$ This is essentially the problem which Draper raises for Stump's account. Whilst Draper admits that Stump's account of suffering as a means of preventing permanent separation from God fulfils both constraints, he argues that there are instances of suffering which fail to meet these constraints. In particular, Draper is interested in discussing cases in which the consent constraint is not met. In the case of suffering in general, Stump can meet this constraint since it is the negative benefit of removing the harm of permanent separation from God which justifies God's allowing an agent to suffer without consent. However, there are people to whom this will not apply, Draper thinks - for instance, if an individual is sufficiently far into the process of sanctification that a permanent lack of union with God after death is not a realistic prospect, then this person's suffering cannot be accounted for as an instance of negative benefit.
} 
This problem can be avoided by thinking more carefully about consent, however. First, let's consider the role of consent in the case of weaning an infant. Weaning is a process which brings about some harm in order to benefit the infant. Even if we focus exclusively on the positive benefits of my being weaned, such as the benefit of my now being able to enjoy a delicious sirloin steak, for instance, which would be unavailable to me if I had not been weaned, it looks like my not consenting is unproblematic here. Why is this the case? Plausibly, the reason why weaning is justifiable without actual consent is because no rational person would deny consent when they were cognitively able to give it. After receiving the benefit of being able to eat sirloin steak, it would be unreasonable of me to have complaint about the suffering inflicted on me when I was weaned, for instance. Thus, perhaps, we can meet the consent constraint by appealing to a kind of subsequent consent: given the future benefits of the spiritual virtues I will receive, and the intimacy of union with God which spiritual weaning allows, no reasonable person would bemoan the harm done to them through this process, regardless of how difficult it is. ${ }^{22}$ The notion of subsequent consent will not get my response to the problem off the hook entirely, however. In case of weaning, the reason that subsequent consent justifies the harm is because the infant is unable to consent. However, the same does not seem to be the case for Mother Teresa.

It is possible to appeal to consent in the spiritual life without the dubious notion of subsequent consent, however. The specific kind of experience which generated the problem discussed in this paper is one in which the individual desires a deeper union with God (condition (3)). But if the individual desires a deeper union with God, and this deeper union with God requires a kind of separation from God, then, we might think, the agent consents to the suffering which results from God's withdrawal. That is, the account developed in this paper can meet the consent constraint simply by appealing to fact that for Mother Teresa and others like her, simply by engaging in the spiritual life and by desiring deeper union with God, they consent to God's withdrawal and the subsequent suffering which this brings. The kind of consent $\mathrm{I}$ have in mind here is summarised well by the words of the Methodist covenant prayer:

I am no longer my own, but thine.

Put me to what thou wilt, rank me with whom thou wilt.

Put me to doing, put me to suffering.

Let me be employed for thee or laid aside for thee, exalted for thee or brought low for thee.

Let me be full, let me be empty.

Let me have all things, let me have nothing.

I freely and heartily yield all things to thy pleasure and disposal.

\footnotetext{
${ }^{22}$ We see this kind of subsequent consent for suffering more generally in Tolstoy's $W$ ar and Peace and Pierre Bezukhov's statement,
}

Well if someone said to me right now, this minute: do you want remain the way you were before captivity, or live through it all over again? For God's sake, captivity again and horsemeat! Once we've thrown off our habitual paths, we think all is lost; but it's only here that the new and the good begins. And as long as there's life, there's happiness. There's much still to come. $(2007,1118)$ 
And now, O glorious and blessed God, Father, Son and Holy Spirit, thou art mine, and I am thine.

So be it.

And the covenant which I have made on earth, let it be ratified in heaven.

Amen. (Wesley \& Wesley, 1981, 387)

If the agent who engages with the spiritual life is willing to make this covenant, or one like it, then, we might think, she consents to whatever means possible to bring about God's will and a closer union with him. It seems very likely that someone such as Mother Teresa, someone who desires union with God and is sufficiently far through the process of sanctification, would be willing to pray this prayer. In fact, there are many examples of prayers and hymns that contain utterances of consent like this - even the most basic form of Christian spirituality, the Lord's prayer, contains within it what looks to be an utterance of consent: 'Your kingdom come, your will be done on earth as it is in heaven' (Matthew 6:10). Or, to give another example, Frances Havergal's hymn 'Take my life', contains the verse:

Take my will, and make it Thine;

It shall be longer mine.

Take my heart; it is Thine own;

It shall be Thy royal throne. $(2010,88)$

The hymns, prayer and liturgies which are an essential part of the spiritual life, give examples of the kind of spiritual consent which individuals give to allow God to withdraw from them. The kind of consent that plays a role in spiritual practices looks to be very similar to the kind of consent given in the wedding vows. In promising to love one's spouse regardless of the future consequences, one consents to the potential future harm that may be inflicted by the marriagethus, thirty years after making the vow, if one's spouse suffers a debilitating illness or loses their means of income, one can hardly claim that they have not consented to these harms, even if they could not predict them. Similarly, in partaking in the spiritual life, in praying that God's will be done, and singing that God 'takes my life', I cannot claim to have not given consent to the dark night of the soul, even if I could not predict or anticipate it. Just by engaging in the spiritual life (and I take it that engagement is necessary for a person who fulfils conditions (1)-(4)), one consents to whatever harm God wills for the benefits that this brings. If this kind of consent is at all plausible, then the problem is never generated for the position advocated in this article.

According to the account I have developed in this article, the benefits gained from spiritual weaning are primarily positive- the development of humility, and a deeper, less superficial relationship with God, for instance. The reason why weaning counts as a morally sufficient reason for God's allowing of harm is that it is entirely consensual. By engaging in the spiritual life, the agent consents wholeheartedly to allow God to bring about closer union with him by whatever means possible. ${ }^{23}$

\footnotetext{
${ }^{23}$ Another way of responding to this objection is to argue that, in fact, the individual does receive negative benefit from the suffering of divine withdrawal. As David Efird and David Worsley (2015) note in their critical review of Wandering in Darkness, Draper's objection to Stump
} 


\section{Conclusion}

The problem of divine withdrawal can be addressed by appealing to the metaphor of weaning as it has been used in the spiritual literature. God can use the experience of separation from him for a higher and ultimately good purpose. The experience of separation from God does not stand against or nullify the importance of experiencing God's presence, but, rather, the experience of God's absence is as important for the believer as the experience of God's presence if she is to experience a deep union of love and a mature spiritual life. We have seen this theme as it is developed in both Kierkegaard's and John of the Cross's work on the spiritual life. Furthermore, this answer to the problem of divine withdrawal has some support from the psychological literature - both dependence and independence are vital stages for developing a union of love. Moreover, by appealing to the kind of consent which is implicit in the spiritual practices involved in an active participation in the Christian spiritual life, we can see that there is a morally sufficient reason for God's allowing agents to suffer the harm of his withdrawal. Whilst the benefits of God's withdrawal are primarily positive benefits (spiritual humility, closeness in relationship to God, etc...) and thus cannot be accounted for by appealing to negative benefit, the harm is a consensual harm and thus, there is no problem with God's allowing this harm to occur. ${ }^{24}$

can be resolved by focusing on the scope of the negative benefit of suffering. Draper's objection is successful only if we assume that the negative benefits which of suffering can be accounted for entirely in the moment of justification. According to Efird and Worsley, Draper's objection relies on the assumption that, for Stump, individuals receive no negative benefits after the moment of justification $(2015,555)$. Their suggestion to prevent Stump's account from failing the consent constraint is to argue that sanctification also has negative benefits to the individual. The kind of negative benefit which is gained from sanctification is a kind of psychic disharmony, or fragmentation. According to this account, God uses suffering to heal our will and our desires in a similar way to the doctor using chemotherapy to heal a cancer. They note, however, that if this defence is to be plausible, then it must be the case that this process of sanctification is never completed in this life $(2015,557)$. That is, there can never be an instance of suffering which fails the constraint condition, since no one will move past the point in which they cannot negatively benefit from suffering in this life.

${ }^{24}$ I would like to thank David Efird, Chris Jay and the members of the St. Benedict Society for the Philosophy of Religion and Philosophical Theology for their feedback on earlier drafts of this article. I would also like to thank the participants of the religious, spirituality and suffering workshop at the University of Leeds, which was part of the Value of Suffering Project. An earlier draft of this article was presented at the workshop and I have found the comments and questions immensely helpful in developing the article. 


\section{REFERENCES}

BLOOM, Anthony, 1970: Beginning to Pray (New York: Paulist Press)

COAKLEY, Sarah, 2016: “Divine Hiddenness or Dark Intimacy?: How John of the Cross Dissolves a Contemporary Philosophical Dilemma"” in Stump and Green (2016)

CONWAY, Daniel (ed.), 2015: Kierkegaard's Fear and Trembling: A Critical Guide (Cambridge: Cambridge University Press)

DRAPER, Paul, 2011: 'Review of Wandering in Darkness: Narrative and the Problem of Suffering' Notre Dame Philosophical Reviews, 27.07.2011, from: https://ndpr.nd.edu/news/24772wandering-in-darkness-narrative-and-the-problem-of-suffering/ accessed on 08/02/16

EFIRD, David \& WORSLEY, David, 2015: 'Critical Review of Eleonore Stump's Wandering in Darkness: Narrative and the Problem of Suffering' Philosophical Quarterly, 65.260, 2015, 547-558

EVANS, C. Stephen, 2004: Kierkegaard's Ethic of Love (Oxford: Oxford University Press)

JOHN of the Cross, The Dark Night of the Soul translated by Mirabai Starr (New York: Riverhead Books, 2002)

KIERKEGAARD, Søren, Either/Or, Part 1(Princeton: Princeton University Press) trans. Edna H. Hong and Howard V. Hong, Kierkegaard's Writings, VII, 1987

Fear and Trembling (Princeton: Princeton University Press) trans. Edna H. Hong and Howard V. Hong, Kierkegaard's Writings, VI, 1983

The Sickness Unto Death (Princeton: Princeton University Press) trans. Edna H. Hong and Howard V. Hong, Kierkegaard's Writings, VI, 1980

GREEN, Adam \& STUMP, Eleonore (eds.), 2016: Hidden Divinity and Religious Belief (Cambridge: Cambridge University Press)

HAVERGAL, Frances, 2010: The Hymns of Frances Ridley Havergal (Minneapolis: Curiosmith), compiled by Charles J. Doe

HONNETH, Axel, 1996: Struggle For Recognition, (Cambridge, Mass.: MIT Press)

HOWLAND, Jacob, 2015: 'Fear and Trembling's “Attunement” as midrash' in Conway (2015)

ODEN, Thomas, 1989: Parables of Kierkegaard (Princeton: Princeton University Press)

PODMORE, Simon, 2013: Struggling with God: Kierkegaard and Temptation of Spiritual Trial (Cambridge: James Clarke \& Co. Ltd.)

QUINN, Philip L. 2006: Essays in the Philosophy of Religion (Oxford: Oxford University Press), edited by Christian B. Miller

RUMBLE, Vanessa, 2015: 'Why Moriah? Weaning and Trauma of Transcendence in Kierkegaard's Fear and Trembling' in Conway (2015) 
SCRUTTON, A.P., 2015. Is Depression a Sin or a Disease? A Critique of Moralizing and Medicalizing Models of Mental Illness. Journal of Disability \& Religion, 19(4), pp.285-311.

STUMP, Eleonore, 2012: 'Atonement and the Cry of Dereliction from the Cross' European Journal For the Philosophy of Religion, Volume 4, Issue 1, Spring 2012

2010: W andering in Darkness (Oxford: Oxford University Press)

TERESA, 2007: Come Be My Light: The Private Writings of the Saint of Calcutta, edited with commentary by Brian Kolodiejchuk (New York: Doubleday)

TOLSTOY, 2007: War and Peace (New York: Vintage Classics, Penguin Random House) translated by Richard Pevear and Larissa Volokhonsky

WESLEY, Charles \& WESLEY, John, 1981: Selected Prayers, Hymns, Journal Notes, Sermons, Letters and Treatises (New York: Paulist Press), edited by Frank Whaling

WINNICOTT, Donald W., 1965: The Maturational Processes and the Facilitating Environment: Studies in the Theory of Emotional Development (London: Karnac Books) 